\title{
Diapause of mouse blastocysts transferred to oviducts of immature mice
}

\author{
V. E. Papaioannou \\ Department of Pathology, Tufts University of School of Medicine, \\ 136 Harrison Avenue, Boston, MA 02111, U.S.A.
}

\begin{abstract}
Summary. Mouse blastocysts transferred to the oviducts of immature females entered a period of diapause from which they could be activated by culture in vitro or by transfer to pseudopregnant recipients. In the tract of immature females, embryos hatched from the zona pellucida, increased cell number to a maximum that is comparable to that of blastocysts delayed by ovariectomy, and some moved to the uterus. Viability of blastocysts retained in the non-progestational, immature tract remained high for 4 days but dropped after 5 or 6 days. This new method of producing a delay in implantation offers precision in determining survival and viability rates and in determining the requirements of diapausing embryos.
\end{abstract}

\section{Introduction}

Embryonic diapause is a normal feature of reproduction in a wide range of mammalian species and can also be induced by several experimental means. The term diapause applies to a period of relative quiescence in the preimplantation embryo which results in a variable delay before implantation. Its occurrence under natural and experimental conditions indicates a remarkable flexibility in the timing of early development. In mice, which are subject to facultative, lactational delay of implantation, experimental diapause can be induced by ovariectomy of females in the early stages of pregnancy followed by daily doses of progesterone (reviewed by McLaren, 1973; Weitlauf, 1974; Aitken, 1977; Bergstrom, 1978). Metabolic quiescence can also be achieved by explantation of blastocysts into serum-free medium although diapause thus induced may differ from lactational or ovariectomy delay (Aitken, 1977).

A different means of producing embryonic diapause was found by Runner \& Gates (1954) who reported that embryos do not implant in prepubertal mice after induced ovulation and mating. Smithberg \& Runner $(1956,1960)$ extended these observations and reported that blastocysts could remain in the uteri of these non-progestational females for long periods while retaining viability for up to 15 days. In their experiments, however, it was not possible to obtain accurate survival rates or to determine what proportion of embryos remained viable under these conditions. The present report describes a simple new method of bringing about embryonic diapause of the blastocyst in prepubertal mice that affords a direct measure of the rate of survival as well as viability of the embryos after different periods of delay.

\section{Materials and Methods}

Mice

Embryos for transfer were flushed from the uteri of random-bred CD-1 females (Charles River), using Medium PB-1 $+10 \%$ fetal calf serum (FCS) (Whittingham \& Wales, 1969; 
Papaioannou \& West, 1981), 3.5 days after mating with CD-1 males (12:00 h on the day of detection of the copulatory plug is considered 0.5 days post coitum). Fully expanded blastocysts were selected for use and any morulae or abnormal embryos were discarded. Older embryos for cell number determination were flushed out of the uterus at 4.5 days post coitum (p.c.) or dissected from implantation sites at $5 \cdot 5$ days p.c.

To provide immature recipients for embryo transfers, naturally mated CD-1 females were allowed to litter and raise their female offspring. Prepubertal females were used between 17 and 32 days of age and were left with their mothers and female sibs for the duration of the experiment. Only females with an imperforate vaginal membrane were selected for use since a perforate vagina is the earliest sign of the onset of puberty. Recipient females for viability testing of embryos were mature CD-1 females in the 3 rd day of pseudopregnancy ( 2.5 days p.c.) induced by mating with a vasectomized male.

\section{Embryo transfers and recovery}

All operations were carried out with tribromoethanol anaesthesia. Between 1 and 10 blastocysts (mean 6.9) were transferred to one oviduct of each immature female using a mouth-controlled micropipette with a flame-polished tip. The pipette was inserted into the ampulla which had been exposed by tearing a hole in the ovarian bursa. Marker air bubbles were placed in the pipette behind and in front of the embryos and could be detected inside the oviduct after a successful transfer. The air bubbles dissolved within about $1 \mathrm{~h}$ of surgery (unpublished observations). Unsuccessful transfers were eliminated from further analysis. After 1-6 days, the immature females were killed, the reproductive tracts were removed and the oviduct and uterus were separately flushed with medium for recovery of embryos. For viability testing, between 2 and 7 recovered embryos were transferred per uterine horn, bilaterally or unilaterally, to pseudopregnant recipients (McLaren \& Michie, 1956). After 8 days (10.5 days p.c. for the recipient female), the recipient was killed and implantation sites were dissected. The developmental state of embryos was assessed by morphology and somite number.

\section{Embryo culture}

Some embryos were cultured to determine time of hatching from the zona pellucida, to test short-term viability and outgrowth success, or to determine cell numbers after different periods of culture. These embryos were placed in drops of $\alpha$-MEM (Flow Laboratories, McLean, VA 22102) with $5 \% \mathrm{FCS}$ and $5 \%$ newborn calf serum under paraffin oil and cultured in $5 \% \mathrm{CO}_{2}$ in air. They were examined daily for hatching, attachment, outgrowth and outgrowth morphology.

\section{Cell counts}

Cell numbers were determined using the DNA dye method of Ebert, Hammer \& Papaioannou (1985). Embryos were incubated for at least $30 \mathrm{~min}$ in medium containing Hoechst 33258 $(10 \mu \mathrm{g} / \mathrm{ml}$ : Polysciences, Warrington, PA 18976). Zonae pellucidae, if present, were removed by brief exposure to acidic Tyrode solution (Nicolson, Yanagimachi \& Yanagimachi, 1975) and the embryos were squashed under a coverslip and photographed with fluorescence optics (Ebert $e t$ al., 1985). The average of two separate nuclear counts from each photograph was used as an estimate of cell number. Embryos recovered after 1-6 days in the immature reproductive tract were counted, as were control embryos recovered from pregnant females at $3.5,4.5$ and .5 .5 days p.c. Some embryos recovered at 3.5 days p.c. were cultured for 1 or 2 days before counts were made. Comparisons of cell numbers were made using Student's $t$ test and $\chi^{2}$ tests were used for other comparisons. 


\section{Results}

\section{Recovery of embryos from reproductive tracts of immature females}

Embryos were recovered from the reproductive tracts of $77 / 84$ immature females 1-6 days after blastocysts were placed in the oviducts. Overall, recovery of embryos was $63 \%$ and the percentage recovered did not markedly decrease with increasing time in the immature female (Table 1). During the course of the experiment, the vaginas of about half of the immature recipients became perforate and 5 females were found to be in oestrus 6 days after embryo transfer. Recovery of embryos from oestrous females was low, $8 / 40$ or $20 \%$, and in these females embryos were found only in the oviducts. From all females in which the vagina became perforate during the course of the experiment, $169 / 301(56 \%)$ of transferred embryos were recovered, whereas from females in which the vagina remained imperforate, $195 / 272(72 \%)$ transferred embryos were removed $\left(\chi^{2}=14\right.$, $P<0.001$ ). If oestrous females are excluded from this analysis, the recovery from females with a perforate vagina was still significantly less than that from females with an imperforate vagina $\left(\chi^{2}=5 \cdot 6, P<0 \cdot 025\right)$.

Many of the transferred blastocysts move to the uterus with time. Amongst females from which embryos were recovered, $42 \%$ ( 32 females) had embryos only in the oviduct, $36 \%$ ( 28 females) had embryos in both sites, and $22 \%$ (17 females) had embryos located in the uterus only. Amongst females with an imperforate vagina, about $50 \%$ of the embryos moved to the uterus per day during the first 2 days but after that time a constant proportion of the originally transferred embryos remained in the oviduct (Table 1).

Table 1. Recovery of mouse embryos from the reproductive tracts of immature females 1-6 days after transfer of blastocysts to the oviducts

\begin{tabular}{lccccc}
\hline $\begin{array}{l}\text { Time of } \\
\text { recovery } \\
\text { (days) }\end{array}$ & $\begin{array}{c}\text { No. of } \\
\text { immature } \\
\text { recipients }\end{array}$ & $\begin{array}{c}\text { Age at } \\
\text { transfer } \\
\text { (days) }\end{array}$ & $\begin{array}{c}\text { No. with } \\
\text { perforate } \\
\text { vagina } \\
\text { at recovery }\end{array}$ & $\begin{array}{c}\text { Embryos } \\
\text { recovered/ } \\
\text { embryos } \\
\text { transferred (\%) }\end{array}$ & $\begin{array}{c}\text { No. of } \\
\text { embryos } \\
\text { in oviduct* } \\
\text { (\% of total } \\
\text { transferred) }\end{array}$ \\
\hline 1 & 6 & $18-32$ & 1 & $28 / 41(68)$ & $21(51)$ \\
2 & 21 & $21-28$ & 8 & $69 / 104(66)$ & $30(29)$ \\
3 & 6 & $24-26$ & 2 & $18 / 32(56)$ & $6(19)$ \\
4 & 22 & $17-31$ & 12 & $113 / 171(66)$ & $22(13)$ \\
5 & 7 & $23-28$ & 4 & $28 / 43(65)$ & $8(19)$ \\
6 & 22 & $17-28$ & 14 & $110 / 186(59)$ & $38(20)$ \\
\hline
\end{tabular}

* Considering only females with imperforate vaginas.

\section{Morphology of recovered embryos}

Most of the embryos were recovered as zona pellucida-free blastocysts. Those recovered from the oviduct were almost always expanded whereas those recovered from the uterus were sometimes flattened such that the blastocoelic cavity was occluded, a common appearance for 'delayed' blastocysts (Bergstrom, 1978; Fiser \& Macpherson, 1982). After a short time in culture, these flattened embryos re-expanded. It appeared that giant cell transformation had occurred in the abembryonic trophectoderm of many embryos, particularly at later recovery times. There was no evidence of attachment to the oviduct or uterine epithelium.

Only 5 of the 366 embryos recovered from immature females appeared abnormal; all were still within the zona pellucida and were recovered from the oviducts. One degenerating embryo was recovered after 4 days; 3 others were recovered after 6 days. Nuclear counts of 10 and 30 were obtained from 2 of these. The 5 th abnormal embryo, recovered after 6 days, appeared as a solid ball of cells and contained 202 nuclei as well as some degenerating nuclear material. 
Hatching from the zona pellucida in the immature reproductive tract

After 1 day immature recipients, $23 / 28(82 \%)$ of blastocysts had hatched from the zona pellucida compared with only $10 / 35(29 \%)$ after 1 day in culture $\left(\chi^{2}=16, P<0.001\right)$. After 2 or more days in immature females, only the 5 abnormal embryos described above remained in their zonae. Empty zonae were sometimes found in the flushings from the oviducts and uterus.

\section{Viability of recovered embryos}

Viability of some of the hatched, morphologically normal blastocysts recovered from the immature females was tested in vivo in pseudopregnant recipients or in vitro. All of the blastocysts that were placed in culture attached and formed typical blastocyst outgrowths with trophoblast giant cells and a central inner cell mass within 4 days. Table 2 shows the numbers explanted from each recovery time and the earliest time that outgrowth occurred. Most embryos attached and outgrew on the 2 nd day of culture after recovery. With increased time in the immature female, no clear trend toward delayed outgrowth after explantation could be seen, although embryos recovered from the oviduct tended to outgrow sooner than embryos recovered from the uterus (Table 2).

Table 2. In-vitro outgrowth of hatched, morphologically normal blastocysts recovered from the immature reproductive tracts of immature female mice 1-6 days after transfer

\begin{tabular}{lccccc}
\hline \multirow{2}{*}{$\begin{array}{l}\text { Days in } \\
\text { immature } \\
\text { female }\end{array}$} & $\begin{array}{c}\text { No. of embryos } \\
\text { cultured }\end{array}$ & 1 day & 2 days & 3 days & 4 days \\
\cline { 3 - 6 } & 7 & 1 & 4 & 2 & 0 \\
1 & 29 & 4 & 21 & 4 & 0 \\
2 & 18 & 0 & 13 & 4 & 1 \\
3 & 19 & 0 & 18 & 1 & 0 \\
4 & 8 & 0 & 8 & 0 & 0 \\
5 & 31 & 0 & 26 & 5 & 0 \\
6 & 112 & $5(5,0)$ & $90(50,40)$ & $16(5,11)$ & $1(0,1)$ \\
Totals* & 12 & &
\end{tabular}

* Numbers in parentheses are numbers of embryos recovered from the oviduct and uterus, respectively.

Although outgrowths in vitro appeared normal, a different picture of embryonic viability emerges from the retransfer of embryos into pseudopregnant recipients after 2-6 days in immature females (Tables $3 \& 4$ ). The implantation rate amongst recipients that became pregnant was high for embryos recovered from the immature females after $2-5$ days ( $78-83 \%$ ) but dropped to $69 \%$ for embryos recovered after 6 days in an immature female. Embryonic development was also progressively impaired; the proportion of normally developing embryos dropped from over $95 \%$ at 2 days to $14-15 \%$ for embryos that spent 5 or 6 days in an immature female. Empty decidual swellings indicated that many embryos died soon after eliciting a decidual response. Somite number amongst embryos classified as normal varied between 10 and 37 but there was no indication of progressive retardation among the embryos with longer periods in the immature tract (Table 3). Embryos recovered from the uterus were more likely to be normal than embryos recovered from the oviduct (Table 4), although the length of time a particular embryo spent in the uterus was unknown.

\section{Cell numbers in recovered embryos}

The mean number of cells in morphologically normal embryos of different ages is presented in Fig. 1 together with cell numbers from implantation delayed embryos at comparable ages from other published papers. The cell number in embryos at 3.5 days p.c., $54 \pm 11.8$ (s.d.), approximately doubled after 1 more day in vivo $(114 \cdot 3 \pm 15 \cdot 9)$, after 1 day in vitro $(122 \pm 20 \cdot 5)$ or 1 day in 


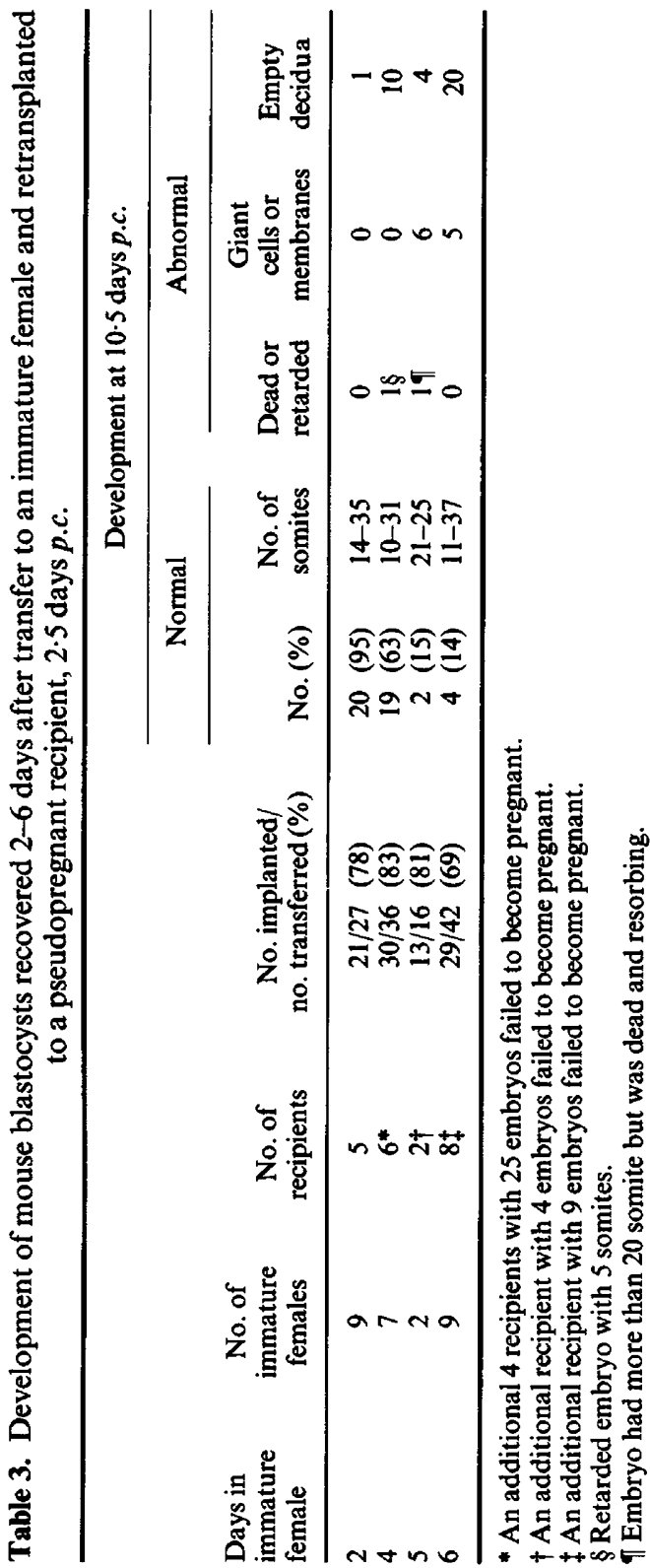


Table 4. Normal midgestation development of embryos recovered from the oviduct or uterus after 2-6 days in immature females and retransfer to pseudopregnant recipients

\begin{tabular}{lcc}
\hline & \multicolumn{2}{c}{$\begin{array}{c}\text { No. of normal embryos/no. implanted } \\
\text { recovered from: }\end{array}$} \\
\cline { 2 - 3 } $\begin{array}{l}\text { Days in } \\
\text { immature female }\end{array}$ & Oviduct (\%) & Uterus (\%) \\
\hline 2 & $13 / 14(93)$ & $7 / 7(100)$ \\
4 & $6 / 14(42)$ & $13 / 16(81)$ \\
5 & $1 / 11(09)$ & $1 / 2(50)$ \\
6 & $1 / 22(05)$ & $3 / 7 \quad(43)$ \\
\hline
\end{tabular}

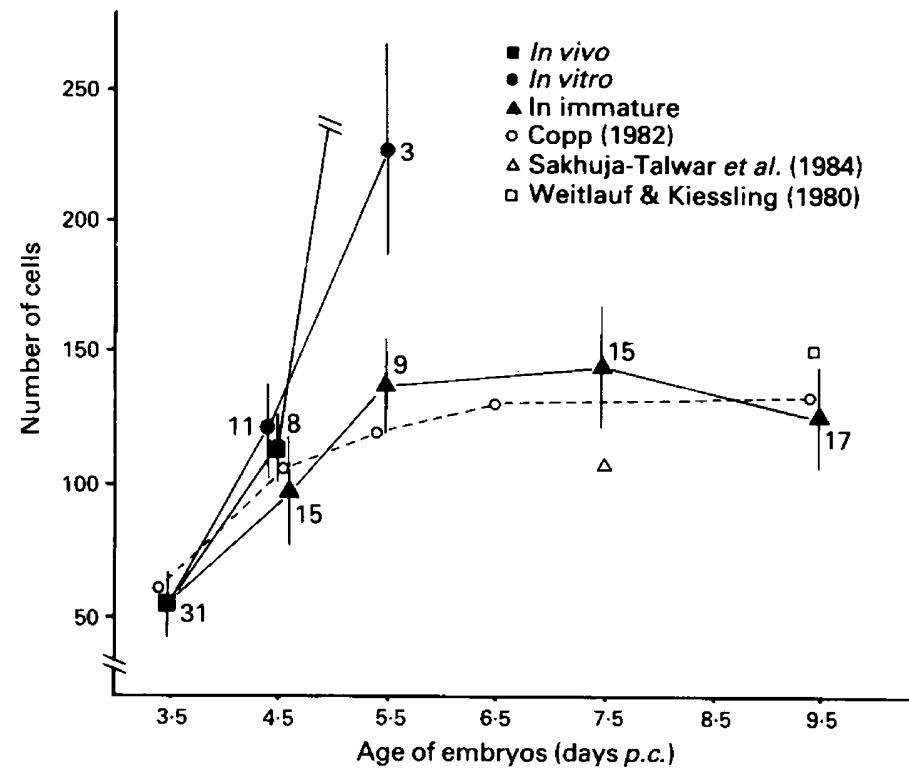

Fig. 1. Mean cell number \pm standard deviation of embryos of different ages from the following groups: in vivo, recovered from pregnant mice at 3.5 and 4.5 days p.c.; in vitro, recovered at 3.5 days p.c. and cultured for 1 or 2 days; in immature, embryos transferred at 3.5 days p.c. to immature mice and recovered 1-6 days later. Number of embryos is indicated at each point. For comparison, mean cell numbers of ovariectomy-delayed embryos from other published studies are also indicated at comparable times post coitum.

immature females $(96 \cdot 1 \pm 21 \cdot 2)$. Values for the last two groups were not significantly different from those for embryos in vivo at $4 \cdot 5$ days p.c., although they were different from one another $(t=3 \cdot 2$, df $24, P<0.01)$.

By 5.5 days p.c., embryos in vivo had implanted and accurate counts were not possible but more than 600 nuclei were counted in each of 4 embryos. Cell number in embryos explanted at 3.5 days p.c. and cultured for 2 days had approximately doubled $(227.7 \pm 41 \cdot 8)$ and was significantly greater than in embryos in immature females for 2 days $(136.9 \pm 17 \cdot 9 ; t=5.5$, df $10, P<0 \cdot 001)$. After 4 days in immature females, cell number increased only slightly $(144.9 \pm 22.7)$ and fell after 6 days $(125.6 \pm 11.4)$. With increasing time in the immature females, a higher proportion of embryos exhibited evidence of degenerating nuclei by the presence of small scattered fragments of fluorescent material. 
At 2 and 6 days, when a sufficient number of embryos were recovered from the uterus and oviduct for comparison, cell numbers in embryos recovered from these two sites were not significantly different although cell numbers in the uterus were consistently higher: at 2 days oviductrecovered embryos had $132.4 \pm 10.4$ cells compared with $140.5 \pm 22.8$ for uterus-recovered embryos and at 6 days the numbers were $123 \cdot 1 \pm 20 \cdot 7$ and $129 \cdot 1 \pm 18 \cdot 3$ for embryos recovered from oviduct and uterus respectively.

\section{Discussion}

The present study demonstrates that implantation can be delayed by transfer of blastocysts to the oviducts of intact, prepubertal females for 1-6 days with no hormonal supplementation, but that viability of the embryos declines rapidly after more than 4 days in the immature tract. Cell numbers increase to a maximum at 4 days in the prepubertal females which corresponds to the maximum number of cells found by others using ovariectomy to produce embryonic diapause (Weitlauf \& Kiessling, 1980; Copp, 1982; Sakhuja-Talwar, Sengupta \& Manchanda, 1984).

Many studies of delayed implantation use females induced to ovulate with gonadotrophins, mated and then ovariectomized. Smithberg \& Runner (1960) used induced ovulation of prepubertal females to study the survival of embryos in the non-progestational uterus. In contrast to these methods of producing embryonic diapause, transfer of embryos to the oviduct of an immature animal has the advantage of eliminating the use of exogenous gonadotrophins and starting with a known number of normal embryos so that recovery and viability rates can be accurately determined. In agreement with Smithberg \& Runner (1960), who found that a subsequent oestrus resulted in a loss of delayed blastocysts through the cervix, our results indicate a loss of embryos from the uterus as immature females approach puberty or enter oestrus. The loss of embryos from females with an imperforate vagina is perhaps best attributed to technical losses at the time of transfer or at the time of recovery. The possibility that abnormal embryos are preferentially lost has been ruled out by the deliberate transfer of abnormal embryos to oviducts of immature females. After 3 days, $68 \%$ of these were recovered (unpublished observations).

The rate of hatching of normal embryos from the zona pellucida, $82 \%$ after 1 day and $100 \%$ after 2 days, is in agreement with other studies of 'delayed' embryos. Bergstrom (1978) reported that $90 \%$ of embryos in ovariectomized females were zona-free by 4.5 days p.c. compared with $100 \%$ from intact females. By 5.5 and 6.5 days p.c., respectively, all embryos were zona-free in ovariectomized and prepubertal mice induced to ovulate (Smithberg \& Runner, 1960; Fiser \& Macpherson, 1982). The persistence of empty zonae pellucidae is to be expected in the absence of progesterone and oestrogen (Orsini \& McLaren, 1967; Hoversland \& Weitlauf, 1981; Fiser \& Macpherson, 1982).

Embryos maintained in immature females for 1-6 days are capable of attachment and outgrowth in vitro, as are 'delayed implanting' embryos from ovariectomized females (Weitlauf \& Kiessling, 1980). Naeslund \& Lundkvist (1978) found that 'early delayed' embryos outgrow in vitro slightly faster than do later, steady-state 'delayed' embryos. There was some suggestion that embryos recovered from the oviduct in the present study outgrew slightly faster than embryos recovered from the uterus, but since it is not known how long any particular embryo spent in the uterus, we cannot determine whether the uterus causes the embryo to reach a steady state sooner. Weitlauf (1971a) found that protein synthesis in blastocysts of pregnant, hypophysectomized females was higher in embryos retained in the oviducts than in the uterus, implying that embryos are not delayed in this site, but since hypophysectomy rather than ovariectomy was used to induce delay, the tube-locked embryos may have been influenced by small amounts of hormones released from the ovaries (Weitlauf, 1974). The use of immature females might help to resolve this question.

Figures on viability and developmental potential of 'delayed' embryos are frequently unavailable since the starting number of embryos is unknown. Smithberg \& Runner (1960) found that 
blastocysts could be recovered from some prepubertal females 46 days after induced ovulation and mating and that implantation could be initiated after 31 days by exogenous oestrogen. Developmental potential of the delayed embryos, however, was greatly reduced after 6-10 days and only a single embryo developed after 15 days in the immature tract. A few studies have used recovery and retransfer of embryos to assess the developmental potential of 'delayed' embryos. Weitlauf (1969) found $37 \%$ normal development after 3 days of ovariectomy delay which was the same as for 'non-delayed' embryos under similar conditions. Weitlauf \& Greenwald (1968) found a drop in viability between 4 and 10 days of ovariectomy delay in the absence of progesterone, and Fiser $\&$ Macpherson (1982), using hormonally primed, prepubertal mice found a sharp decline in viability after 7-9 days of delay. Progesterone, which is present during natural lactation delay when embryos remain viable for up to 15 days, is reportedly necessary for survival of delayed embryos (Kirby, 1971) but Weitlauf \& Greenwald (1968) found normal viability of embryos delayed for 10 days with no progesterone and Weitlauf (1971b) found no effect of progesterone on retention of delayed blastocysts or subsequent implantation and development after 10 days of delay, although development was adversely affected by the absence of progesterone during extended periods of delay (20-30 days).

In addition to the study of embryonic diapause, there are other potential uses for the technique described here. Kaufman, Barton \& Surani (1977) have demonstrated that a period of implantation delay has a beneficial effect on the development or diploid parthenogenetic embryos and postulated that the extended preimplantation period allows the embryo to reach a higher cell number before implantation. Tsunoda \& McLaren (1983) obtained better development of half embryos by using serial, asychronous transfers to pseudopregnant females to extend the overall preimplantation time by 3-4 days, which may have allowed regulation of the cell number before implantation. The present method may prove to be a convenient in-vivo culture system that could be used to increase the viability of embryos that have been subject to experimental manipulations that tend to decrease cell number or division rate.

I thank Jonathan Flax for expert technical assistance and Karl Ebert for helpful discussion. This research was supported by a Basil O'Connor Starter Research Grant No. 5-379 from the March of Dimes and by the National Science Foundation under grant No. PCM81-14950.

\section{References}

Aitken, R.J. (1977) Embryonic diapause. In Development in Mammals, Vol. 1, pp. 307-359. Ed M. H. Johnson. North Holland Publishing Co., Amsterdam.

Bergstrom, S. (1978) Experimentally delayed implantation. In Methods in Mammalian Reproduction, pp. 419 435. Ed. J. C. Daniel, Jr. Academic Press, New York.

Copp, A.J. (1982) Effect of implantational delay on cellular proliferation in the mouse blastocyst. $J$. Reprod. Fert. 66, 681-685.

Ebert, K.M., Hammer, R.E. \& Papaioannou, V.E. (1985) A simple method for counting nuclei in the preimplantation mouse embryo. Experientia (in press).

Fiser, P.S. \& Macpherson (1982) Survival of preimplantation embryos in the uteri of mice induced to superovulate and subsequently ovariectomized. $J$. Reprod. Fert. 64, 33-36.

Hoversland, R.C. \& Weitlauf, H.M. (1981) Lysis of the zona pellucida and attachment of embryos to the uterine epithelium in ovariectomized mice treated with oestradiol-17 $\beta$ and progesterone. J. Reprod. Fert. 62, 111-116.
Kaufman, M.H., Barton, S.C. \& Surani, M.A.H. (1977) Normal postimplantation development of mouse parthenogenetic embryos to the forelimb bud stage. Nature, Lond. 265, 53-55.

Kirby, D.R.S. (1971) Blastocyst-uterine relationship before and during implantation. In Biology of the Blastocyst, pp. 393-411. Ed. R. J. Blandau. University of Chicago Press, Chicago.

McLaren, A. (1973) Blastocyst activation. In The Regulation of Mammalian Reproduction, pp. 321-328. Eds S. Segal, R. Crozier, P. Corfman \& P. Cundliffe. C. C. Thomas, Springfield.

McLaren, A. \& Michie, D. (1956) Studies on the transfer of fertilized mouse eggs to uterine foster-mothers. $I$. Factors affecting the implantation and survival of native and transferred eggs. J. exp. Biol. 33, 394-416.

Naeslund, G. \& Lundkvist, O. (1978) Effect of the endocrine state of blastocyst donors on the time required for initiation of outgrowth. Uppsala J. med. Sci. 83, 135-139.

Nicolson, G.L., Yanagimachi, R. \& Yanagimachi, H. (1975) Ultrastructural localization of lectin-binding 
sites on the zonae pellucidae and plasma membranes of mammalian eggs. J. Cell Biol. 66, 263-274.

Orsini, M.W. \& McLaren, A. (1967) Loss of the zona pellucida in mice, and the effect of tubal ligation and ovariectomy. J. Reprod. Fert. 13, 485-499.

Papaioannou, V.E. \& West, J.D. (1981) Relationship between the parental origin of the $\mathrm{X}$ chromosomes, embryonic cell linage and $\mathbf{X}$ chromosome expression in mice. Genet. Res., Camb. 37, 183-197.

Runner, M.N. \& Gates, A. (1954) Conception in prepuberal mice following artificially induced ovulation and mating. Nature, Lond. 174, 222-223.

Sakhuja-Talwar, D., Sengupta, J. \& Manchanda, S.K. (1984) Carbohydrate metabolism in delayed implanting mouse blastocysts undergoing activation in utero and in vitro. J. Reprod. Fert. 70, 185-189.

Smithberg, M. \& Runner, M.N. (1956) The induction and maintenance of pregnancy in prepuberal mice. J. exp. Zool. 133, 44I-457.

Smithberg, M. \& Runner, M.N. (1960) Retention of blastocysts in nonprogestational uteri of mice. J. exp. Zool. 143, 21-31.

Tsunoda, Y. \& McLaren, A. (1983) Effect of various procedures on the viability of mouse embryos containing half the normal number of blastomeres. J. Reprod. Fert. 69, 315-322.
Weitlauf, H.M. (1969) Temporal changes in protein synthesis by mouse blastocysts transferred to ovariectomized recipients. J. exp. Zool. 171, 481-486.

Weitlauf, H.M. (1971a) Protein synthesis by blastocysts in the uteri and oviducts of intact and hypophysectomized mice. J. exp. Zool. 176, 35-40.

Weitlauf, H.M. (1971b) Effect of progesterone on survival of blastocysts in the uteri of ovariectomized mice. J. Endocr. 51, 375-380.

Weitlauf, H.M. (1974) Metabolic changes in the blastocysts of mice and rats during delayed implantation. $J$. Reprod. Fert. 39, 213-224.

Weitlauf, H.M. \& Greenwald, G.S. (1968) Survival of blastocysts in the uteri of ovariectomized mice. $J$. Reprod. Fert. 17, 515-520.

Weitlauf, H.M. \& Kiessling, A.A. (1980) Comparison of overall rates of RNA synthesis in implanting and delayed implanting mouse blastocysts in vitro. Devl Biol. 77, 116-129.

Whittingham, D.G. \& Wales, R.G. (1969) Storage of twocell mouse embryos in vitro. Aust. J. biol. Sci. 22 , 1065-1068.

Received 12 March 1985 